\title{
Chemical study and evaluation of antioxidant activity and $\alpha$-glucosidase inhibition of Myrciaria strigipes O. Berg (Myrtaceae)
}

\author{
Rafael D. Faitanin', João V. D. Gomes², Patrícia M. Rodrigues ${ }^{3}$, Luís Fernando T. de Menezes ${ }^{3}$, Álvaro C. Neto ${ }^{4}$, \\ Rita C. R. Gonçalves ${ }^{1}$, Rodrigo R. Kitagawa ${ }^{1}$, Dâmaris Silveira ${ }^{2}$, Claudia M. Jamal ${ }^{1 *}$ \\ 'Department of Pharmaceutical Sciences, Federal University of Espírito Santo, Campus Maruípe, Vitória, Brazil. \\ ${ }^{2}$ Department of Pharmacy, Faculty of Health Sciences, University of Brasilia, Campus Darcy Ribeiro, Brasília, Brazil. \\ ${ }^{3}$ Department of Agrarian and Biological Sciences, Federal University of Espírito Santo, Campus São Mateus, São Mateus, Brazil. \\ ${ }^{4}$ Department of Chemistry, Federal University of Espírito Santo, Campus Goiabeiras, Vitória, Brazil.
}

\section{ARTICLE INFO}

Article history:

Received on: $15 / 12 / 2017$

Accepted on: 21/02/2018

Available online: $30 / 03 / 2018$

\section{Key words:}

Myrciaria strigipes, HPLC,

Phenolic compounds,

Triterpenes, Antioxidant

activity, $\alpha$-glucosidase.

\begin{tabular}{l}
\hline ABSTRACT \\
Myrciaria strigipes O. Berg (Myrtaceae) is a Brazilian native species, endemic to Bahia and Espírito Santo, and \\
known popularly as "cambucá da praia". This study aimed to evaluate the chemical profile of ethanol extract of leaves \\
from $M$. strigipes (EEF), and the two in vitro activities: antioxidant and inhibition of $\alpha$-glucosidase. The column \\
chromatography separation gave friedelin (1), glutinol (2), $\beta$-sitosterol (3), 28-hydroxyfriedelin (4), and ursolic acid \\
(5). The chromatographic profile of EEF by HPLC $(354 \mathrm{~nm})$ allowed the identification of three phenolic compounds: \\
ellagic acid (6), hyperoside (7), and isoquercitrin $(\mathbf{8})$. The extract EEF showed antioxidant activity in both models \\
DPPH and ABTS, with $\mathrm{EC}_{50}$ of $61.79 \pm 2.97$ and $23.72 \pm 0.48 \mu \mathrm{g} / \mathrm{mL}$, respectively. Trolox, used as a standard, showed \\
$\mathrm{EC}_{50}$ of $4.60 \pm 0.82$ and $1.08 \pm 0.05 \mu \mathrm{g} / \mathrm{mL}$, respectively. The obtained result of the inhibition assay on the enzyme \\
activity of $\alpha$-glucosidase revealed that $\mathrm{EEF} \mathrm{had} \mathrm{an} \mathrm{EC}_{50}$ value of $40.66 \pm 0.81 \mu \mathrm{g} / \mathrm{mL}$, close to the positive standard \\
deoxynojirimycin $\left(\mathrm{EC}_{50}=37.30 \pm 4.41 \mu \mathrm{g} / \mathrm{mL}\right)$. Therefore, this study contributed to the knowledge of the chemical \\
and biological properties of $M$. strigipes and will subsidize future studies of this species.
\end{tabular}
(5). The chromatographic profile of EEF by HPLC (354 nm) allowed the identification of three phenolic compounds: ellagic acid (6), hyperoside (7), and isoquercitrin (8). The extract EEF showed antioxidant activity in both models $\mathrm{DPPH}$ and $\mathrm{ABTS}$, with $\mathrm{EC}_{50}$ of $61.79 \pm 2.97$ and $23.72 \pm 0.48 \mu \mathrm{g} / \mathrm{mL}$, respectively. Trolox, used as a standard, showed activity of $\alpha$-glucosidase revealed that $\mathrm{EEF}$ had an $\mathrm{EC}_{50}$ value of $40.66 \pm 0.81 \mu \mathrm{g} / \mathrm{mL}$, close to the positive standard and biological properties of M. strigipes and will subsidize future studies of this species.

\section{INTRODUCTION}

Brazil is the owner of the largest and richest genetic diversity of plant species. However, only a few percentage of this biodiversity has been investigated about chemical composition and biological activity (Luna et al., 2005). Myrciaria strigipes O. Berg (Myrtaceae), known as "cambucá da praia" and "cabeludinha da praia", is a Brazilian native species, endemic to Bahia and Espírito Santo (Sobral et al., 2015), and there is a lack of studies regarding its chemical and biological activities.

Myrciaria genus has around 100 known species, and 21 are native to Brazil. Myrciaria genus can be found in diverse regions, including countries in South America and Central America. In Brazil, the species are widespread in various biomes, such as

"Corresponding Author

Claudia M. Jamal, Department of Pharmaceutical Sciences, Federal

University of Espirito Santo, Campus Maruipe, Vitória, Brazil.

E-mail:cmjamal@gmail.com
Amazon Forest, Caatinga, Cerrado, Atlantic Forest and Pampa, and are grown mainly in the states of Rio de Janeiro, São Paulo, Minas Gerais and Espírito Santo (Borges et al., 2014). Active compounds belonging to several classes of secondary metabolites have been identified in Myrciaria species. Borges et al. (2014) reported 49 substances, including various phenolic compounds such as kaempferol, quercetin, and isoquercitrin flavonoids; delphinidin 3-O-glucoside and cyanidin 3-O-glucoside anthocyanins; gallic acid and ellagic acid; d-limonene and 1,8-cineole monoterpenes, and globulol and (2E,6E)-farnesyl acetate sesquiterpenes. In the search for bioactive molecules from plant species, it is necessary to carry out multidisciplinary studies that approach chemical and biological aspects.

The reactive species, for example, hydroxyl, superoxide anion, hypochlorous acid, hydrogen peroxide, nitric oxide, and peroxynitrite, are continuously generated in the organism and involved in the regulation of cell growth, phagocytosis, intercellular signaling, as well as in the synthesis of essential biological 
substances and energy production. However, the excess of reactive species is a serious problem to human homeostasis and has a substantial contribution to the pathogenesis of many diseases such as cancer, gastric disorders, premature aging, cataracts, arthritis, neurodegenerative and cardiovascular diseases (Bhattacharyya et al., 2014). On the other hand, antioxidant defense system counteracts the excess of reactive species in the organism and comprises substances able to regenerate or prevent the oxidative damage caused by reactive species. This defense consists of enzymatic antioxidants produced by the body, such as superoxide dismutase, glutathione peroxidase and catalase, and antioxidants from the diet as ascorbic acid (vitamin C), $\alpha$-tocopherol (vitamin E) and phenolic compounds (Bhattacharyya et al., 2014). Therefore, the research of plant antioxidant activity has great importance in search of new compounds capable of preventing or minimizing the deleterious effects of reactive species.

Diabetes mellitus is a serious global public health since it affects millions of people and its prevalence increases at an alarming rate every year. In 2015, the disease affected around 415 million adults (20-79 years) in the world, and the forecast to 2040 is this number will increase to 642 million. In 2015, in Brazil, about 14 million adults were affected by this disease, and it is expected to reach 23.3 million in 2040. Moreover, it is estimated that 5.0 million of global deaths in 2015 were caused by diabetes (International Diabetes Federation, 2015).

Diabetes is a chronic metabolic disease caused by inherited or acquired deficiency in insulin secretion and by decreasing the cellular response to insulin; it is characterized by an abnormal postprandial increase of blood glucose level (Cheng and Fantus, 2005). One therapeutic approach for controlling diabetes is inhibition of $\alpha$-glucosidase activity to reduce postprandial hyperglycemia. $\alpha$-Glucosidase is an enzyme present in the membrane of the intestinal cells and promoting the hydrolysis of $\alpha-1,4$ glucosidic bonds of oligo and disaccharides, generating molecules of monosaccharide which can be absorbed by the organism (Yin et al., 2014). The main available inhibitors of this enzyme for clinical use are acarbose, miglitol, and voglibose (Ríos et al., 2015). However, the use of these hypoglycemic agents can cause various gastrointestinal side effects such as abdominal distention and discomfort, diarrhea and flatulence, thereby limiting their therapeutic use. Currently, the medicinal plants have been extensively studied in search of a more suitable, safe and efficient inhibitors of $\alpha$-glucosidase, that will may be used in the treatment of diabetes (Cheng and Fantus, 2005).

Considering it is important to know about biological and chemical properties of medicinal plants, this paper describes the chemical study and evaluation of antioxidant activity and $\alpha$-glucosidase inhibition of ethanol extract of leaves from Myrciaria strigipes O. Berg, Although the importance of this species for Restinga inhabitants, due the edible fruits (Lopes and Lobão, 2013), as far we know, there is no study about this plant concerning chemical composition or potential biological activity (Borges et al., 2014).

\section{MATERIAL AND METHODS}

\section{General experimental procedures}

NMR spectra were recorded in $\mathrm{CDCl}_{3}$ on a Varian 400 $\mathrm{MHz}$ spectrometer $\left({ }^{13} \mathrm{C}\right.$ at $\left.100 \mathrm{MHZ}\right)$, and chemical shifts were reported in ppm. High Performance Liquid Chromatography was performed on a LaChrom Elite ${ }^{\circledR}$ (Hitachi) system, equipped with a L2130 pump, a L2200 injector, a L2300 oven column, maintained at $25^{\circ} \mathrm{C}$, a $\mathrm{L} 2455$ diode array detector and an $\mathrm{C} 18$ reversedphase column $(150 \times 4.6 \mathrm{~mm}$; particle size of $5 \mu \mathrm{m}$; Merck $)$. The sample was solubilized in methanol (HPLC grade) to give a concentration of $1 \mathrm{mg} / \mathrm{ml}$, and then $10 \mu \mathrm{L}$ of this solution was injected into the chromatograph. As mobile phase was employed $1 \%$ phosphoric acid solution and acetonitrile in gradient system $\left(\mathrm{H}_{3} \mathrm{PO}_{4}\right.$ 1\%:MeCN: 0 min 90:10; $40 \mathrm{~min}$ 70:30; $50 \mathrm{~min}$ 50:50; $51 \mathrm{~min} 90: 10 ; 60 \mathrm{~min} 90: 10$ ) and a flow rate of $0.6 \mathrm{~mL} / \mathrm{min}$. The data capture was performed using the ExChrom Elite ${ }^{\circledR}$ software. The compounds present in the sample were compared according to their UV-Vis spectrum (230 to $400 \mathrm{~nm}$ ) and the retention time with several commercial standards (caffeic acid, chlorogenic acid, ellagic acid, ferulic acid, gallic acid, kaempferol, rosmarinic acid, hesperetin, hesperidin, hyperoside, isoquercitrin, myricetin, quercetin, rutin, vitexin, isovitexin, myricetin, and resveratrol). The analyses were performed in triplicate.

\section{Plant material}

Myrciaria strigipes O. Berg (Myrtaceae) leaves were collected in São Mateus, Espírito Santo, Brazil, in June 2014 and identified by Prof. Luis Fernando Tavares de Menezes (Federal University of Espírito Santo). A voucher specimen has been deposited in the VIES Herbarium at the Federal University of Espírito Santo under identification number 25.038.

\section{Extraction and isolation}

The collected leaves were dried for about 72 hours in an oven at $38-40^{\circ} \mathrm{C}$ and ground into coarse powder by knife mill. The dried and powdered plant material (267.5 g) was macerated at room temperature with ethanol. After filtration, the solvent was removed under reduced pressure, at a temperature below $40^{\circ} \mathrm{C}$, providing ethanol extract of leaves from $M$. strigipes (EEF) (yield of $14 \% \mathrm{w} / \mathrm{w})$.

An aliquot of the EEF (26.8 g) was submitted to silica gel 60 column chromatography, using a gradient system with hexane, chloroform, and methanol as eluents. Were obtained 420 fractions of approximately $225 \mathrm{~mL}$ each, which were monitored by thin layer chromatography and the fractions with similar profiles were collected in several groups, and those with the highest yields were subjected to purification classic processes, such as washes, recrystallization, and re-chromatography, which led to the isolation of 5 substances. These substances were submitted to spectrometric analysis.

\section{Evaluation of antioxidant activity of EEF from $M$. strigipes}

The EEF antioxidant activity was assessed in vitro by spectrophotometric chemical methods using the synthetic free radicals DPPH and ABTS. The free radical scavenging activity was calculated as the percentage of inhibition $(\% \Delta)$ according to the following equation: $\% \Delta=\left[\left(\mathrm{Ab}_{\text {control }}-\mathrm{Ab}_{\text {sample }}\right) / \mathrm{Ab}_{\text {control }}\right] \times 100$. The $\mathrm{EC}_{50}$ was estimated by linear regression of data obtained. Trolox was used as a standard antioxidant. The concentrations tested were $100,50,25,12.5,6.25$ and $3.125 \mu \mathrm{g} / \mathrm{mL}$. All the results were expressed as the mean of three triplicates \pm standard deviation. 


\section{$D P P H$ radical scavenging activity}

The capacity of EEF to scavenge DPPH free radicals was evaluated according to the methodology proposed by Gülçin et al. (2003) with modifications. In 96-well microplate was added to each well $200 \mu \mathrm{L}$ of $\mathrm{DPPH}^{*}$ ethanolic solution $0.004 \%$ (w/v) and subsequently added $100 \mu \mathrm{L}$ of extract solution. The reaction proceeded for 10 minutes at room temperature and protected from light. The absorbance was then read at $540 \mathrm{~nm}$ (Microplate reader - iMark, BIO-RAD). As a reference of maximum absorption was used the reading obtained with $200 \mu \mathrm{L}$ of $\mathrm{DPPH}^{*}$ solution added to $100 \mu \mathrm{L}$ of ethanol. The blank consisted of $300 \mu \mathrm{L}$ of ethanol.

\section{ABTS radical scavenging activity}

The capacity of EEF to scavenge ABTS free radicals was evaluated according to the methodology proposed by Re et al. (1999) with modifications. ABTS radical cation $\left(\mathrm{ABTS}^{\cdot+}\right)$ was produced by reacting of $5 \mathrm{mLABTS}$ aqueous solution $(7 \mathrm{mM})$ with $88 \mu \mathrm{L}$ potassium persulfate $(2.45 \mathrm{mM})$ and keeping the mixture at room temperature and protected from light for 16 hours before use. The $\mathrm{ABTS}^{*+}$ solution formed was diluted with ethanol to an absorbance of 0.700 at $750 \mathrm{~nm}$, and $1 \mathrm{~mL}$ aliquot of this solution was mixed with $10 \mu \mathrm{L}$ of extract solution. After 10 minutes, 200 $\mu \mathrm{L}$ of this mixture was added to the 96-well microplate. The absorbance was then read at $750 \mathrm{~nm}$ (Microplate reader - iMark, BIO-RAD). As a reference of maximum absorption was used the reading obtained with $1 \mathrm{~mL}$ of $\mathrm{ABTS}^{++}$solution added to $10 \mu \mathrm{L}$ of ethanol. The blank consisted of $200 \mu \mathrm{L}$ of ethanol.

\section{Determination of $\alpha$-glucosidase inhibitory activity}

The capacity of EEF to inhibit the $\alpha$-glucosidase enzyme was evaluated according to the methodology proposed by Shinde et al. (2008) with modifications. In 96-well microplate $20 \mu \mathrm{L}$ of $\alpha$-glucosidase $(1 \mathrm{U} / \mathrm{mL})$ (Sigma-Aldrich) was incubated at $25^{\circ} \mathrm{C}$ for 5 minutes with $20 \mu \mathrm{L}$ of extract solution $(1000 \mu \mathrm{g} / \mathrm{mL})$ in $50 \mathrm{mM}$ phosphate buffer ( $\mathrm{pH} 6.8$ ). After the preincubation, $40 \mu \mathrm{L}$ of $1 \mathrm{mM}$ p-nitrophenyl- $\alpha$-D-glucopyranoside was added, and the mixture was incubated at $37^{\circ} \mathrm{C}$ for 30 minutes. The reaction was stopped by the addition of $100 \mu \mathrm{L}$ of $10 \% \mathrm{NaHCO}_{3}$, and the $\alpha$-glucosidase activity was determined spectrophotometrically by measuring the quantity of p-nitrophenol released from p-nitrophenyl- $\alpha$-Dglucopyranoside at $405 \mathrm{~nm}$. The inhibitory activity was determined by comparing the enzyme activity in the absence and the presence of the evaluated inhibitor. Deoxynojirimycin was used as a positive control. The $\mathrm{EC}_{50}$ of EEF was estimated by nonlinear regression of data obtained with values of concentration ranging between 7.81 and $250 \mu \mathrm{g} / \mathrm{mL}$. All the statistical analyses were performed using the software GraphPad Prism 6.0 ${ }^{\circledR}$.

\section{RESULTS AND DISCUSSION}

The ethanol extract of leaves (EEF) from M. strigipes was chromatographed over sílica gel column and providing five known substances: friedelin (1), glutinol (2), $\beta$-sitosterol (3), 28-hydroxyfriedelin (4), and ursolic acid (5) (Figure 1). These substances were identified by comparison of ${ }^{13} \mathrm{C}-\mathrm{NMR}$ chemical shifts with data reported in the literature.

Friedelin (1). ${ }^{13} \mathrm{C}-\mathrm{NMR}\left(\mathrm{CDCl}_{3}, 100 \mathrm{MHz}\right): \delta(\mathrm{ppm})$ 22.4 (C-1), 41.7 (C-2), 213.4 (C-3), 58.4 (C-4), 42.3 (C-5), 41.4 (C-6), 18.4 (C-7), 53.2 (C-8), 37.6 (C-9), 59.6 (C-10), 35.8 (C-11),
30.6 (C-12), 38.4 (C-13), 39.8 (C-14), 32.6 (C-15), 36.2 (C-16), 30.1 (C-17), 42.9 (C-18), 35.5 (C-19), 28.3 (C-20), 32.9 (C-21), 39.4 (C-22), 7.0 (C-23), 14.8 (C-24), 18.1 (C-25), 20.4 (C-26), 18.8 (C-27), 32.2 (C-28), 35.2 (C-29), 31.9 (C-30). Substance 1 was identified by comparison of ${ }^{13} \mathrm{C}-\mathrm{NMR}$ chemical shifts with data reported in Sousa et al. (2012).

Glutinol (2). ${ }^{13} \mathrm{C}-\mathrm{NMR}\left(\mathrm{CDCl}_{3}, 100 \mathrm{MHz}\right): \delta(\mathrm{ppm}) 18.4$ (C-1), 28.0 (C-2), 76.5 (C-3), 39.4 (C-4), 141.7 (C-5), 122.2 (C-6), 23.8 (C-7), 49.8 (C-8), 35.0 (C-9), 47.6 (C-10), 34.8 (C-11), 30.5 (C-12), 41.0 (C-13), 38.0 (C-14), 32.2 (C-15), 36.2 (C-16), 30.2 (C-17), 43.2 (C-18), 35.2 (C-19), 28.4 (C-20), 33.3 (C-21), 39.1 (C-22), 29.1 (C-23), 25.6 (C-24), 16.4 (C-25), 19.8 (C-26), 18.6 (C-27), 32.5 (C-28), 34.7 (C-29), 32.2 (C-30). Substance 2 was identified by comparison of ${ }^{13} \mathrm{C}-\mathrm{NMR}$ chemical shifts with data reported in Miranda et al. (2012).

$\beta$-sitosterol (3). ${ }^{13} \mathrm{C}-\mathrm{NMR}\left(\mathrm{CDCl}_{3}, 100 \mathrm{MHz}\right): \delta(\mathrm{ppm})$ 37.4 (C-1), 32.1 (C-2), 72.0 (C-3), 42.5 (C-4), 140.9 (C-5), 121.9 (C-6), 31.8 (C-7), 32.1 (C-8), 50.3 (C-9), 36.7 (C-10), 21.2 (C-11), 39.9 (C-12), 42.5 (C-13), 56.9 (C-14), 24.5 (C-15), 28.4 (C-16), 56.2 (C-17), 12.0 (C-18), 19.6 (C-19), 36.3 (C-20), 19.2 (C-21), 34.1 (C-22), 26.3 (C-23), 46.0 (C-24), 29.3 (C-25), 20.0 (C-26), 18.9 (C-27), 23.2 (C-28), 12.1 (C-29). Substance 3 was identified by comparison of ${ }^{13} \mathrm{C}-\mathrm{NMR}$ chemical shifts with data reported in Patra et al. (2010).

28-hydroxyfriedelin (4). ${ }^{13} \mathrm{C}-\mathrm{NMR}\left(\mathrm{CDCl}_{3}, 100 \mathrm{MHz}\right)$ : $\delta$ (ppm) 22.2 (C-1), 41.5 (C-2), 213.1 (C-3), 58.2 (C-4), 42.1 (C-5), 41.2 (C-6), 18.2 (C-7), 52.4 (C-8), 37.4 (C-9), 59.4 (C-10), 35.4 (C-11), 30.1 (C-12), 39.3 (C-13), 38.1 (C-14), 31.2 (C-15), 29.1 (C-16), 35.1 (C-17), 39.4 (C-18), 34.5 (C-19), 28.1 (C-20), 33.3 (C-21), 31.4 (C-22), 6.8 (C-23), 14.6 (C-24), 18.0 (C-25), 19.0 (C-26), 19.2 (C-27), 68.0 (C-28), 32.8 (C-29), 34.2 (C-30). Substance 4 was identified by comparison of ${ }^{13} \mathrm{C}$-NMR chemical shifts with data reported in Sidjui et al. (2015).

Ursolic acid (5). ${ }^{13} \mathrm{C}-\mathrm{NMR}\left(\mathrm{CDCl}_{3}, \mathrm{CD}_{3} \mathrm{OD}, 100 \mathrm{MHz}\right)$ : $\delta$ (ppm) 38.5 (C-1), 26.4 (C-2), 78.4 (C-3), 38.4 (C-4), 55.1 (C-5), 18.1 (C-6), 32.8 (C-7), 39.2 (C-8), 47.3 (C-9), 36.7 (C-10), 23.0 (C-11), 125.3 (C-12), 138.0 (C-13), 41.8 (C-14), 27.8 (C-15), 24.0 (C-16), 47.6 (C-17), 52.6 (C-18), 38.9 (C-19), 38.7 (C-20), 30.4 (C-21), 36.6 (C-22), 27.7 (C-23), 15.0 (C-24), 15.3 (C-25), 16.6 (C-26), 23.2 (C-27), 180.3 (C-28), 16.6 (C-29), 20.7 (C-30). Substance 5 was identified by comparison of ${ }^{13} \mathrm{C}$-NMR chemical shifts with data reported in Miranda et al. (2015).

The presence of terpenes in Myrtaceae species is a striking feature (Padovan et al., 2014). Thus, this study corroborated this statement, since were isolated and identified five substances of this class. Although they are already known compounds, and described in plants, is the first time that they are reported on a Myrciaria species.

The chromatographic profile of EEF by HPLC (354 nm) is shown in Figure 2. The signals obtained from the chromatogram were compared according to its absorption spectrum in the UV-Vis (230 to $400 \mathrm{~nm}$ ), and retention time with various commercial standards, allowed the identification of three phenolics compounds, ellagic acid (6), hyperoside (7), and isoquercitrin (8) (Figure 1). Although they are substances already described in Myrciaria genus, it is the first time they are reported to M. strigipes. The chromatogram showed other signals, but it was not possible to identify them with the available standards. 
<smiles>CC[C@H](CC[C@H](C)C1CCC2C3CC=C4C[C@@H](O)CC[C@]4(C)C3CC[C@]21C)C(C)C</smiles>

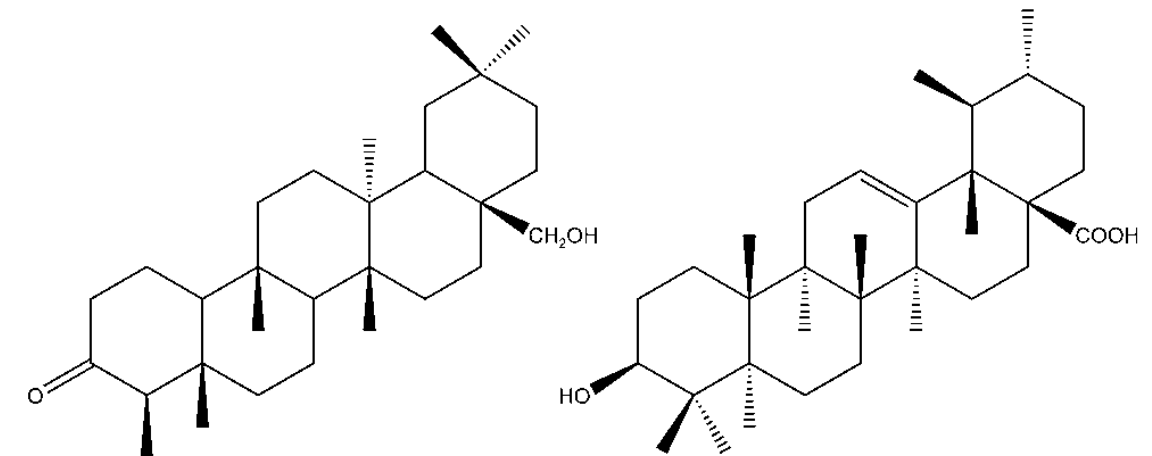

4<smiles>O=c1c(OC2OC3C(CO)C(O)C(O2)[C@H](O)C3O)c(-c2ccc(O)c(O)c2)oc2cc(O)cc(O)c12</smiles>

7
5

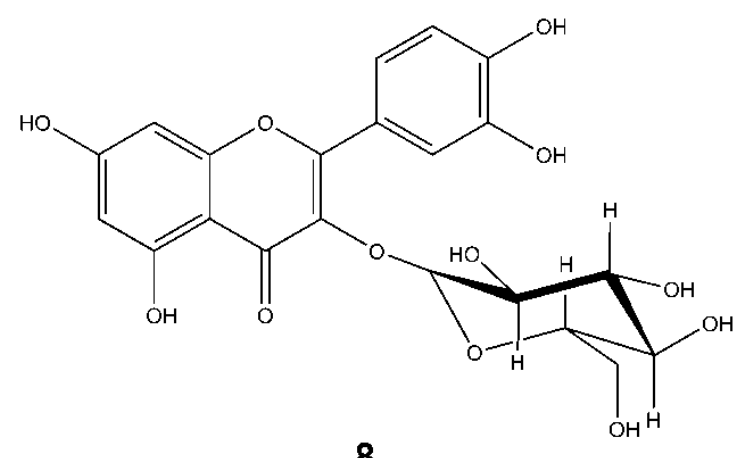

Fig. 1: Substances identified in M. strigipes.

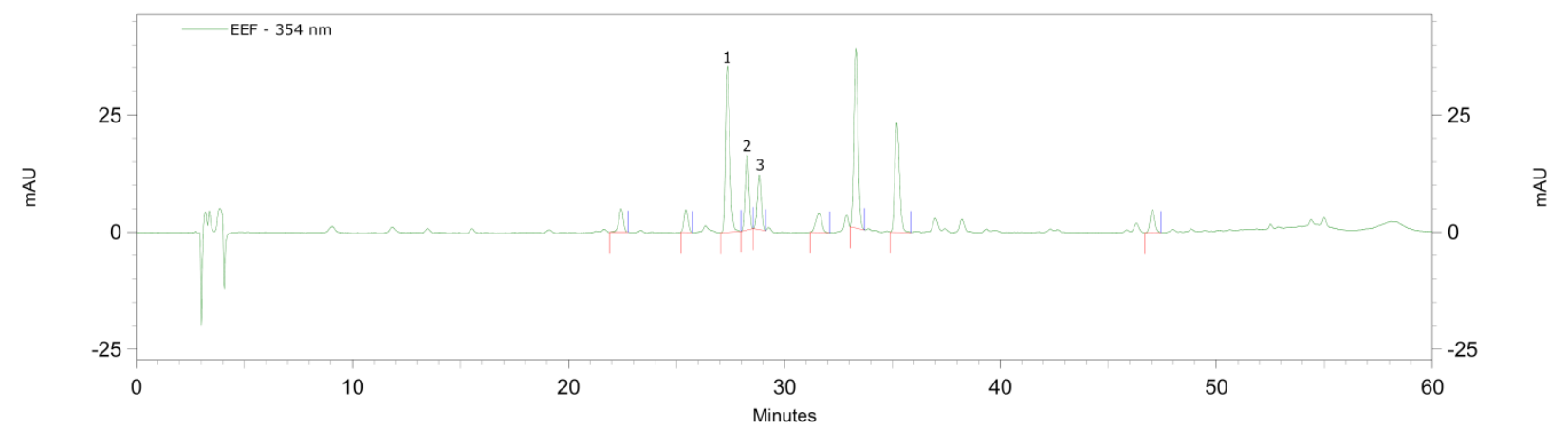

Fig. 2: Chromatographic profile of EEF from Myrciaria strigipes by HPLC at $354 \mathrm{~nm}$. 1- ellagic acid (6); 2- hyperoside (7), 3-isoquercitrin (8).

There are several methods for in vitro evaluation of antioxidant activity of plant extracts, among them stand out from those using synthetic free radicals, such as 2,2-diphenyl-1picrylhydrazyl (DPPH) and 2,2'-azinobis-(3-ethylbenzothiazoline6-sulfonic acid) (ABTS) (Pyrzynska and Pękal, 2013). The
DPPH and ABTS assays are characterized by being fast, easy and reproducible, and widely used for preliminary investigation of antioxidant activity (Mishra et al., 2012; Re et al., 1999). The use of the both assays is due to the sensitivity differences in the capture of the two radicals, depended the chemical characteristics 
of the compounds present in the extract. This fact may have as justification the phenomenon of steric blockade, which may prevent or delay the reaction in the DPPH assay. The closer the hydroxyl groups in the sample are to the unpaired nitrogen of the DPPH radical, the greater the ease of reaction, so the activity against the DPPH radical can be influenced by the structural characteristics of the antioxidant molecule (Alisi et al., 2012).

The EEF showed antioxidant activity in both evaluation models (Figure 3). In DPPH assay, the extract showed inhibition of $73.34 \pm 2.17 \%$ at concentration of $100 \mu \mathrm{g} / \mathrm{mL}$ and $\mathrm{EC}_{50}$ (effective concentration $50 \%$ ) of $61.79 \pm 2.97 \mu \mathrm{g} / \mathrm{mL}$. In ABTS assay, the EEF showed inhibition of $91.79 \pm 0.78 \%$ at a concentration of $50 \mu \mathrm{g} / \mathrm{mL}$, demonstrated statistically significant similarity with Trolox at a concentration of $100 \mu \mathrm{g} / \mathrm{mL}$, and showed $\mathrm{EC}_{50}$ of 23.72 $\pm 0.48 \mu \mathrm{g} / \mathrm{mL}$. Trolox showed $\mathrm{EC}_{50}$ of $4.60 \pm 0.82$ and $1.08 \pm 0.05$ $\mu \mathrm{g} / \mathrm{mL}$ in DPPH and ABTS assays, respectively.
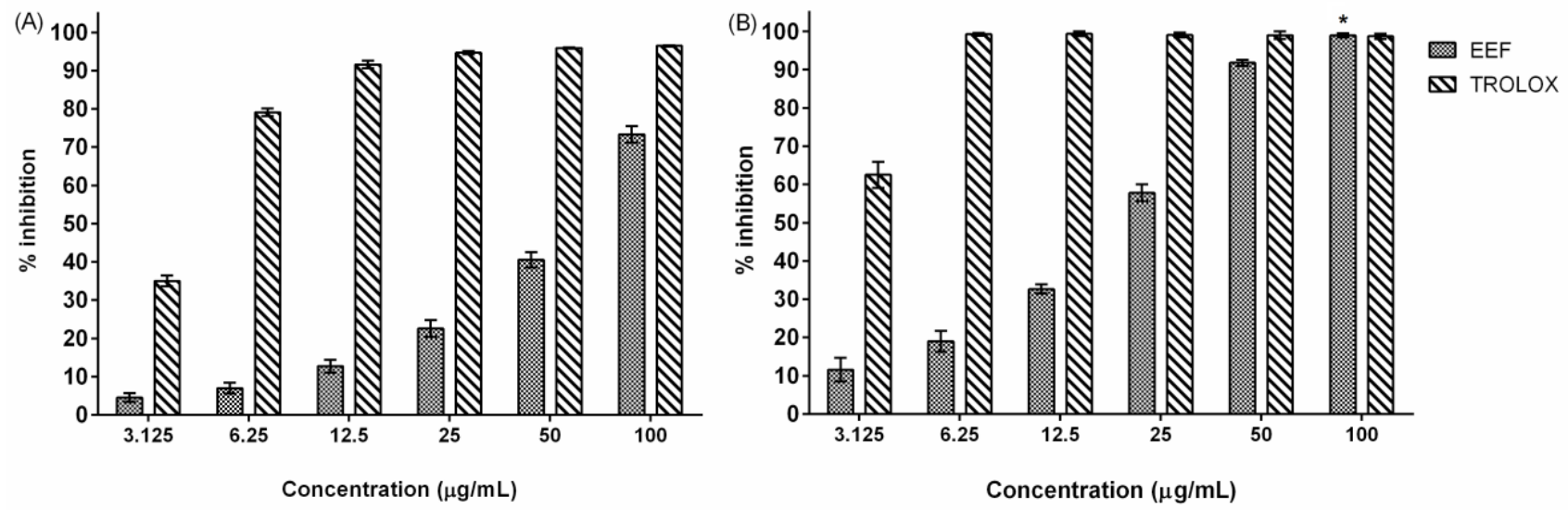

Fig. 3: Antioxidant activity evaluation of EEF from Myrciaria strigipes. (A) DPPH assay; (B) ABTS assay. *p $>0.05$, when compared to Trolox.

The results of the inhibition assay on the enzyme activity of $\alpha$-glucosidase demonstrated that EEF has high potential inhibition, showed $84.62 \pm 0.87 \%$ of inhibition and $\mathrm{EC}_{50}$ of 40.66 $\pm 0.81 \mu \mathrm{g} / \mathrm{mL}$. The positive standard deoxynojirimycin showed inhibition of $94.85 \pm 0.03 \%$ and $\mathrm{EC}_{50}$ of $37.30 \pm 4.41 \mu \mathrm{g} / \mathrm{mL}$.

Oxidative stress plays an important role in diabetes pathology. The increase of oxidative markers level in diabetes type 2 patients is well reported in the literature (Brownlee et al., 1984; Maritim et al., 2003; Evans et al., 2002). Therefore, the use of antioxidant drugs can contribute to the diabetes control. The antioxidant activity can be associated with the synergistic effects of various active compounds which contribute in different degrees to the activity. Studies have shown that the antioxidant activity has a strong positive correlation with the presence of phenolic compounds (Mustafa et al., 2010) and seems to exist a positive relation between antioxidant activity and $\alpha$-glucosidase inhibition.

Based on the chromatographic profile of EEF by HPLC, it can be inferred that the identified phenolic compounds contribute to the antioxidant capacity. Moreover, studies have demonstrated the antioxidant activity of ellagic acid (6) (Hayes et al., 2011) lutein, sesamol and ellagic acid, hyperoside (7) (Zhou et al., 2013), and isoquercitrin (8) (Li et al., 2011).

The inhibition of $\alpha$-glucosidase by EEF from $M$. strigipes may be associated with the presence of compounds belonging to the different chemical class. Several studies have reported the inhibition potential of tannins (Gunawan-Puteri and Kawabata, 2010), phenolic acids (You et al., 2012), triterpenes (Wang et al., 2013), and flavonoids (Pereira et al., 2011). Among the phenolic acids, ellagic acid (6) stands out for having a high $\alpha$-glucosidase inhibitory activity (You et al., 2012), then the presence of this compound in the extract may be contributing to the observed inhibitory activity. Furthermore, ursolic acid (5), also present in the EEF, is a compound with recognized ability to inhibit $\alpha$-glucosidase (Wang et al., 2013).

Therefore, this work reported, for the first time, chemical aspects and biological activity of Myrciaria strigipes O. Berg. Five substances of terpenes class and three phenolic compounds were identified. The EEF showed antioxidant activity when tested by synthetic radicals, leading the continued evaluation of this activity against reactive species of biological interest. Moreover, the ethanol extract showed promising inhibitory activity on $\alpha$-glucosidase, an enzyme involved in diabetes disease.

Moreover, this report is in line with the Brazilian Policies concerning Medicinal Plants and Herbal Medicines designed to ensure the research of native medicinal plant species to allow the safe and rational use of them in the Public Health System. Also, studying native plants can promote the sustainable use of biodiversity, the development of technologies and innovations and the strengthening of productive chains.

\section{CONFLICT OF INTERESTS}

There are no conflicts of interest.

\section{ACKNOWLEDGMENT}

The authors are grateful to Postgraduate Program in Pharmaceutical Sciences from the Federal University of Espirito Santo (PPGCFAR - UFES), National Council for Scientific and Technological Development (CNPq), and Coordination for the Improvement of Higher Education Personnel (CAPES).

\section{REFERENCES}

Alisi MA, Brufani M, Cazzolla N, Ceccacci F, Dragone P, Felici M, Furlotti G, Garofalo B, Bella A, Lanzalunga O, Leonelli F, Bettolo RM, Maugeri C, Migneco LM, Russo V. DPPH radical scavenging activity of paracetamol analogues. Tetrahedron, 2012; 68:10180-10187. 
Bhattacharyya A, Chattopadhyay R, Mitra S, Crowe SE Oxidative stress: an essential factor in the pathogenesis of gastrointestinal mucosal diseases. Physiol Rev, 2014; 94:329-354.

Borges LL, Conceição EC, Silveira D. Active compounds and medicinal properties of Myrciaria genus. Food Chem, 2014; 153:224-233.

Brownlee M, Vlassara H, Cerami A. Nonenzymatic glycosylation and the pathogenesis of diabetic complications. Ann Intern Med, 1984; 101:527-537.

Cheng AYY, Fantus IG. Oral antihyperglycemic therapy for type 2 diabetes mellitus. Can Med Assoc J, 2005; 172:213-226.

Evans JL, Goldfine ID, Maddux BA, Grodsky GM. Oxidative stress and stress-activated signaling pathways: a unifying hypothesis of type 2 diabetes. Endocr Rev, 2002; 23:599-622.

Gülçin İ, Oktay M, Kıreçcı E, Küfrevıoğlu Öİ. Screening of antioxidant and antimicrobial activities of anise (Pimpinella anisum L.) seed extracts. Food Chem, 2003; 83:371-382.

Gunawan-Puteri MDPT, Kawabata J. Novel $\alpha$-glucosidase inhibitors from Macaranga tanarius leaves. Food Chem, 2010; 123:384-389.

Hayes JE, Allen P, Brunton N, O'Grady MN, Kerry JP. Phenolic composition and in vitro antioxidant capacity of four commercial phytochemical products: olive leaf extract (Olea europaea L.), lutein, sesamol and ellagic acid. Food Chem, 2011; 126:948-955.

International Diabetes Federation Diabetes Atlas - Seventh Edition. 2015. Available at: http://www.diabetesatlas.org [Accessed 20 Oct 2016].

Li R, Yuan C, Dong $\mathrm{C}$, Shuang $\mathrm{S}$, Choi MMF. In vivo antioxidative effect of isoquercitrin on cadmium-induced oxidative damage to mouse liver and kidney. N-S Arch Pharmacol, 2011; 383:437-445.

Lopes LCM, Lobão AQ. Etnobotânica em uma comunidade de pescadores artesanais no litoral norte do Espírito Santo, Brasil. Bol Mus Biol Mello Leitão, 2013; 32:29-52.

Luna JS, Santos AF, Lima MRF, Omena MC, Mendonça FAC, Bieber LW, Sant'Ana AEG. A study of the larvicidal and molluscicidal activities of some medicinal plants from northeast Brazil J Ethnopharmacol, 2005; 97:199-206.

Maritim AC, Sanders RA, Watkins JB 3rd. Diabetes, oxidative stress, and antioxidants: a review. J Biochem Mol Toxicol, 2003; 17:24-38.

Miranda MLD, Garcez FR, Garcez S. Triterpenos e outros constituintes dos frutos de Enterolobium contortisiliquum (Vell.) Morong (Fabaceae). Rev Virt Quim, 2015; 7:2597-2605.

Miranda MLD, Souza AF, Rodrigues ED, Garcez FR, Garcez WS. Constituintes químicos das folhas de Riedeliella graciliflora Harms (Leguminosae). Quim Nova, 2012; 35:1306-1311.

Mishra K, Ojha H, Chaudhury NK. Estimation of antiradical properties of antioxidants using DPPH assay: A critical review and results. Food Chem, 2012; 130:1036-1043.

Mustafa RA, Abdul Hamid A, Mohamed S, Bakar FA. Total phenolic compounds, flavonoids, and radical scavenging activity of 21 selected tropical plants. J Food Sci, 2010; 75:C28-35.

Padovan A, Keszei A, Külheim C, Foley WJ. The evolution of foliar terpene diversity in Myrtaceae. Phytochem Rev, 2014; 13:695-716.
Patra A, Jha S, Murthy PN, Manik, Sharone A. Isolation and characterization of stigmast-5-en-3 $\beta$-ol ( $\beta$-sitosterol) from the leaves of Hygrophila spinosa T. Anders. Int J Pharma Sci Res, 2010; 1:95-100.

Pereira DF, Cazarolli LH, Lavado C, Mengatto V, Figueiredo MSRB, Guedes A, Pizzolatti MG, Silva FRMB. Effects of flavonoids on $\alpha$-glucosidase activity: potential targets for glucose homeostasis. Nutrition, 2011; 27:1161-1167.

Pyrzynska K, Pękal A. Application of free radical diphenylpicrylhydrazyl (DPPH) to estimate the antioxidant capacity of food samples. Anal Methods, 2013; 5:4288-4295.

Re R, Pellegrini N, Proteggente A, Pannala A, Yang M, RiceEvans C. Antioxidant activity applying an improved ABTS radical cation decolorization assay. Free Radical Bio Med, 1999; 26:1231-1237.

Ríos J, Francini F, Schinella G. Natural products for the treatment of type 2 Diabetes Mellitus. Planta Med, 2015; 81:975-994.

Shinde J, Taldone T, Barletta M, Kunaparaju N, Hu B, Kumar S, Placido J, Zito SW. $\alpha$-Glucosidase inhibitory activity of Syzygium cumini (Linn.) Skeels seed kernel in vitro and in Goto-Kakizaki (GK) rats. Carbohyd Res, 2008; 343:1278-1281.

Sidjui LS, Melong R, Mahiou-Leddet V, Herbette G, Tchinda AT, Ollivier E, Folefoc GN. Triterpenes and Lignans from Kigelia africana. J Appl Pharm Sci, 2015; 5:1-6.

Sobral M, Proença C, Souza M, Mazine F, Lucas E. 2015. Myrtaceae in Lista de Espécies da Flora do Brasil. [ONLINE] Available at: http://floradobrasil.jbrj.gov.br/jabot/floradobrasil/FB10801 [Accessed 13 Mar 2017].

Sousa GF, Duarte LP, Alcântara AFC, Silva GDF, Vieira-Filho SA, Silva RR, Oliveira DM, Takahashi JA. New triterpenes from Maytenus robusta: structural elucidation based on NMR experimental data and theoretical calculations. Molecules, 2012; 17:13439-13456.

Wang ZW, Wang JS, Luo J, Kong LY. $\alpha$-Glucosidase inhibitory triterpenoids from the stem barks of Uncaria laevigata. Fitoterapia, 2013; 90:30-37.

Yin Z, Zhang W, Feng F, Zhang Y, Kang W. $\alpha$-Glucosidase inhibitors isolated from medicinal plants. Food Sci Hum Wellness, 2014; 3:136-174.

You Q, Chen F, Wang X, Jiang Y, Lin S. Anti-diabetic activities of phenolic compounds in muscadine against alpha-glucosidase and pancreatic lipase. LWT - Food Sci Technol, 2012; 46:164-168.

Zhou W, Oh J, Li W, Kim DW, Lee SH, Na M. Phytochemical studies of Korean endangered plants: a new flavone from Rhododendron brachycarpum G. Don. B. Korean Chem Soc, 2013; 34:2535-2538.

How to cite this article:

Faitanin RD, Gomes JVD, Rodrigues PM, de Menezes LFT, Neto ÁC, Gonçalves RCR, Kitagawa RR, Silveira D, Jamal $\mathrm{CM}$. Chemical study and evaluation of antioxidant activity and $\alpha$-glucosidase inhibition of Myrciaria strigipes O. Berg (Myrtaceae). J App Pharm Sci, 2018; 8(03): 120-125. 